\title{
The Teaching Techniques and Strategies Use by the Dressmaking Teachers Perceive by the Dressmaking Students
}

\author{
${ }^{1}$ Mary Rose Dancel Castro, ${ }^{2}$ Precious D. Andres, ${ }^{3}$ Mark - Jhon R. Prestoza \\ ${ }^{1,2,3}$ Reina Mercedes Vocational and Industrial School \\ Senior High School Department \\ Tallungan, Teina Mercedes, Isabela, Philippines \\ maryrosedancelcastro@gmail.com ${ }^{1}$, preciousdandres@gmail.com², markjhonprestoza@gmail.com³ \\ DOI: https://doi.org/10.37134/ajatel.vol8.5.2018 \\ Received: 20 Jun 2018; Accepted: 11 Sept 2018; Published: 30 December 2018
}

\begin{abstract}
The purpose of this research study was to determine the teaching techniques and strategies use by the dressmaking teachers perceive by the dressmaking students of Reina Mercedes Vocational and Industrial School. This research aims to answer the following: What are the teaching techniques used by the dressmaking teachers? ; What are the strategies used by the dressmaking teachers? ; What are the perception of the dressmaking students of these techniques and strategies of the dressmaking students about effectiveness of selected teaching techniques and strategies of their teachers? Three research questions guided the study. The descriptive quantitative research design was adopted. The stratified random sampling techniques was used to select a sample of 90 students. Research findings showed that the teaching techniques employed by the dressmaking teachers are the following: The teacher sets due date to accomplish the projects/job, The teacher catchers the student's attention when they are noisy, The Teacher corrects students' errors and supplies them with the correct answers and The teacher uses concrete examples in delivering the lessons and the teaching strategies used by the dressmaking teachers are the following: The teacher orients the students in maintaining and troubleshooting a sewing machine, The teacher guides the students the proper use of sewing tools and equipment, The teacher motivates the students by giving them credits if they accomplish the task or activity before the deadline, The teacher demonstrates actual drafting, cutting, lay outing demonstration before the students do their work and The teacher assist students in doing their works and the techniques and strategies employed by the dressmaking teachers really help the students in their study.
\end{abstract}

Keywords: Teaching techniques, strategies, dressmaking students, perceive, survey

\section{INTRODUCTION}

Education is one of the primary needs of everyone. It is priceless and no one can buy or borrow either because it is within you. But education is not just like a candy wrapper that you can pick anywhere. You need to strive and face the challenges and hindrances that block on your way for you to achieve the sweet success. Education has tremendous effects that can determine how successful a person's life will be and the job that he will obtain. It can decide what one will do for the rest of this life and it can determine how one will live their life.

Researches, Philippines is one of the countries having the lowest performance in terms of education. According to the study of Aivazidis C. Lazaridone M. and Hellden GF. (2006), some factors that affect the quality of education are performance of parental guidance, financial problem and attitude.

There are other factors that can affect academic performance of students but teachers have a big contribution to this. The way the teacher delivers his/her lessons is the class, how he/she motivate his students, how he/she manage the class are just some factors that contributes in the performance of the students. 
Every teacher has different techniques and strategies that they use to achieve their goals in class. But they should consider the common interest and the learning capacity of the learners. They should also have the principle of concern and respect for students and student learning. Appropriate assessment and feedback is also part of strategies and techniques of a teacher. Good teachers foster sense of students control over learning and interest in the subject. It has nothing to do with making things hard nor putting pressure to students. It relies with benevolence and humility trying to help students feel that a subject can be mastered; it encourages them to try things out for themselves and succeed and something quickly. It is worth stressing that we know that student who experience teaching of the kind that permits control for the learner not only learn better, but making sure that they enjoy learning as well.

\section{STATEMENT OF THE PROBLEM}

This study aims to assess the teaching techniques and strategies of the dressmaking teachers of Reina Mercedes Vocational and Industrial School.

Specifically, the following questions will be answered:

1. What are the techniques use by the dressmaking teachers?

2. What are the strategies use by the dressmaking teachers?

3. What are the perception of the dressmaking students of these techniques and strategies about the effectiveness of selected teaching techniques and strategies of their teachers?

\section{SIGNIFICANCE OF THE STUDY}

It is great of importance that the researchers conduct this study to assess the teaching techniques and strategies of the dressmaking teachers of Reina Mercedes Vocational and Industrial School. Also, this study may provide information about the different teaching skills and capacity of the dressmaking teachers on their assessed performance. The result of the study is deemed helpful to the following:

The Administrator. The result of the study helped the school administrators to assess the strengths and weaknesses of the educators and be able to make remedies on the site that need improvement.

Dressmaking Teachers. The findings of the study serve as a reference in the assessment of their efficiency in teaching the subject as well as helping them improve their performance in teaching the subject, and if necessary, redesign the teaching techniques and strategies that they use for them to meet the satisfaction level of the students and parents.

Parents. This study informed them on the quality of the education that is being received by their children as provided by the institution through the services rendered by the educators.

Dressmaking Students. This study serves as their way of assessing the effectiveness of the teaching techniques and strategies applied by their teachers. It also serve as means of measuring their satisfaction level with regards to the performance of the instructors.

\section{REVIEW OF RELATED LITERATURE AND STUDY}

This chapter discusses and presence the related literature and studies, both foreign and local, which provide a comprehensive review, insights and directions in pursuing this study. Information is cited in various sources and references including books, newspapers, magazines, journals and the internet. 


\section{Advantages of the Teaching Techniques and Strategies to the Students}

Helping students understand better in the classroom is one of the primary concerns of every teacher. Teachers need to motivate students how to learn. According to Schlecty (1994), students who understand the lesson tend to be more engaged and show different characteristics such as attraction to do work, persistence in the work despite challenges and obstacles, and take visible delight in accomplishing their work. In developing students' understanding to learn important concepts, teacher may use a variety of teaching strategies and would work best for his/her students.Wlodkowski and Ginsberg (1995), research has shown that no teaching strategy will consistently engage all learners. The key is helping students' prior knowledge in understanding new concepts.

Brock (1976), Cashin (1979), and Lucas (1990), stated that it is necessary for teachers to work from students' strengths and interests by finding out why students are in your class and what are their expectations. Therefore, it is important to take into consideration students' needs and interests so as focus instruction that is applicable to different groups of students with different levels.

On the other hand, Merrill (2007) determined the basic principles of an instructional process depending on certain instructional design models, the most important feature of these principles is that they are commonly found in all instructional models in general.

Ornstein and Lastey (2004), having effective teachers has an effect on the achievements of the students. Having well-trained and effective teachers is a useful of schools to intensify learning for all students. Properly trained teachers are skillful in using all possible teaching techniques and methods to impart lessons to the students.

According to Boiser (2004), effective teaching is only possible if teachers will also consider the understanding of the complexity of classroom teaching and learn to develop strategies that will enable them to continually evaluate and improve the teaching-learning effectiveness. Strategies are plans or ways to meet or address certain situations, from one's knowing of his students, his job as a teacher, and what teachers are supposed to develop in themselves to be of better service to the learners.

Stronge (2002) pointed out that teacher evaluation is, first, about documenting the quality of teachers performance; then, its focus shifts to helping teachers improve their performance as well as holding them accountable for their work. In recent years, the teacher has proven time and again to be the most influential school-related force in student achievement.

Ormod (2008) stated that some students seem to learn better when information is presented through words, whereas others seem to learn better when it is presented in the form of pictures.

\section{Effective Teaching Techniques and Strategies to the Students}

Akhtar (2007), studied that lecture method is the most effective teaching methods to increase knowledge retention and induce a positive change in environmental attitudes.

However, Costa Van Rensburg and Rushtun (2007) found that the lecture style method was discouraged in favour of a more interactive teaching style, and that participation increase the retention of factual knowledge.

Witzel (2003) found out that students using the concrete and representational level achieved significantly higher pretest scores that the students who used only abstract representation.

Study done by Aivazidis et. al. (2006) showed that a direct experienced of learning increase knowledge and caused a change in learners' attitudes towards the environment.

Hijazi and Naqui (2009), mentioned two types of factors that affect the students' academic performance. The internal and external factors. Research shows that students' performance depends on many factors such as learning facilities, gender and age differences.

According to the study conducted by Ning and Downing (2010) aspects like motivation and study strategies in study behavior were also discovered to be of importance to the academic performance.

Weng (2002) discovered that teaching research has found that teachers demonstrate patterns of beliefs that guide their instructional choices.

A study conducted by Lord (2001) found that certain elements of learning were enhanced by using cooperative learning, in that they showed an enhancement of thinking skills, reading and writing skills and the learning environment. 
Hughes (2009) researched the relationship between teaching styles perceived by students and teaching styles adopted by instructors. The result revealed that students felt they learned better when instructors employed a teaching style that was more interactive.

Chen (2008) conducted that students performed better academically if they felt that their teacher established rules to manage their learning but at the same time listened to students' opinion towards learning and gave them feedback.

A study conducted by Wang (2000) showed that skilled learners used more frequently to facilitate their own learning.

Diehl and Reese (2010) revealed that students who were shown elaborated metaphors reflected better performance in higher level thinking inferences.

\section{METHODOLOGY}

This study utilized a Descriptive Quantitative survey design focused on the perceptions of the dressmaking students about selected teaching techniques and strategies, and their effects employed by the dressmaking teachers of Reina Mercedes Vocational and Industrial School.

The respondents of this study were 90 dressmaking students from grade 10,11 , and 12 . The accuracy of the data was dependent on the responses through the distribution of questionnaires prepared by the researchers as the assessment tool of the study.

A survey questionnaire consisting of three parts was developed by the researchers for the purpose of this study. The content of the first part was the techniques use by the dressmaking teacher second was the strategies employed by the dressmaking teachers, and the third part was the effects of these techniques and strategies in the students.

This was used to determine the performance of the dressmaking teachers of Reina Mercedes Vocational and Industrial School.

\begin{tabular}{|c|c|c|}
\hline Options & Quantitative Description & Interval \\
\hline 1 & Never & $1.00-1.79$ \\
\hline 2 & Seldom & $1.80-2.59$ \\
\hline 3 & Uncertain & $2.60-3.39$ \\
\hline 4 & Sometimes & $3.40-4.19$ \\
\hline 5 & Always & $4.20-5.00$ \\
\hline
\end{tabular}




\section{RESULTS AND DISCUSSION}

Table 1. Mean, Rank, Standard Deviation and Description of the Teaching Techniques as Perceived by the Dressmaking Students.

\begin{tabular}{|c|c|c|c|}
\hline Statement & Mean & S. D. & Description \\
\hline Teaching techniques & & & \\
\hline The teacher demonstrates the steps in drafting, lay outing and cutting. & 4.444 & 0.9612 & Always \\
\hline The teacher sets due date to accomplish the project/job. & 4.322 & 1.2616 & Always \\
\hline The teacher catches the student's attention when they are noisy & 4.25 & 1.114 & Always \\
\hline $\begin{array}{l}\text { The teacher corrects students' errors constructively and supplies them } \\
\text { with th/e correct answers. }\end{array}$ & 4.079 & 1.1304 & Sometimes \\
\hline The teacher uses concrete examples in delivering the lessons. & 3.922 & 1.114 & Sometimes \\
\hline The teacher asks evaluative questions during and after the discussion. & 3.91 & 1.249 & Sometimes \\
\hline $\begin{array}{l}\text { The teacher allows the students to use their mother tongue in sharing their } \\
\text { ideas, thoughts and feeling towards the lesson. }\end{array}$ & 3.878 & 1.0687 & Sometimes \\
\hline The teacher writes the key terms on the board and gives emphasis on it. & 3.82 & 1.903 & Sometimes \\
\hline The teacher provides outline advance organizer or visual guides. & 3.787 & 1.1329 & Sometimes \\
\hline The teacher inserts jokes in explaining the topic. & 3.607 & 1.0936 & \\
\hline $\begin{array}{l}\text { The teacher uses modulated and different rhythm of voices to motivate the } \\
\text { students. }\end{array}$ & 3.375 & 1.3245 & $\begin{array}{r}\text { Sometimes } \\
\text { Uncertain }\end{array}$ \\
\hline The teacher incorporates story-telling in teaching the lessons. & 3.184 & 1.3077 & Uncertain \\
\hline The teacher presents energizer/motivation before the classes start. & 3.18 & 1.2019 & Uncertain \\
\hline $\begin{array}{l}\text { The teacher uses power point presentation in teaching/delivering the } \\
\text { lessons }\end{array}$ & 2.689 & 1.5335 & Uncertain \\
\hline The teacher plays video presentation/clips in presenting the lessons. & 2.278 & 1.317 & Seldom \\
\hline
\end{tabular}

The table presented above is the assessed work performance of the dressmaking teachers of Reina Mercedes Vocational and Industrial School.

As seen in the table, the teaching techniques of the dressmaking teachers as perceived as "always" are the following: The teacher demonstrates the steps in drafting, lay outing and cutting , The teacher sets due date to accomplish the project/job, and The teacher catches students' attention.

While the teaching techniques perceived as "sometimes" are the following: The teacher corrects students' errors constructively and supplies them with the correct answers, The teacher uses concrete examples in delivering the lessons, The teacher asks evaluative questions during and after the discussion, The teacher allows the students to use their mother tongue in sharing their ideas, thoughts, and feeling towards the lesson, The teacher writes key terms on the board and give emphasis on it, The teacher provides outline advance organizer or visual guides, and The teacher inserts jokes in explaining the topic.

As cited on the study of Omrod (2008), it reveals that students seem to learn better when the teacher demonstrates first the activities before performing the said activity. 
Table 2. Mean, Rank, Standard Deviation and Description of the Teaching Strategies as Perceived by the Dressmaking Students

\begin{tabular}{|c|c|c|c|}
\hline Statement & Mean & S.D. & Description \\
\hline \multicolumn{4}{|l|}{ Teaching Strategies } \\
\hline $\begin{array}{l}\text { The teacher orients the students in maintaining and troubleshooting a } \\
\text { sewing machine. }\end{array}$ & 4.567 & 0.8618 & Always \\
\hline $\begin{array}{l}\text { The teacher guides the students the proper use of sewing tools and } \\
\text { equipment. }\end{array}$ & 4.389 & 1.073 & Always \\
\hline $\begin{array}{l}\text { The teacher motivates the students by giving them credits if they } \\
\text { accomplish the task or activity before the deadline. }\end{array}$ & 4.333 & 1.0167 & Always \\
\hline $\begin{array}{l}\text { The teacher demonstrates actual drafting, cutting, lay outing } \\
\text { demonstration before the students do their work. }\end{array}$ & 4.315 & 1.1129 & Always \\
\hline The teacher assists students in doing their works. & 3.78 & 1.1414 & Sometimes \\
\hline The teacher uses modules in disseminating the ideas or the lesson. & 3.644 & 1.1149 & Sometimes \\
\hline The teacher uses diorama in teaching and presenting the lessons. & 3.375 & 1.3245 & Uncertain \\
\hline $\begin{array}{l}\text { The teachers uses semantic webbing in presenting, explaining, and } \\
\text { elaborating the topic or the lesson. }\end{array}$ & 3.202 & 1.3539 & Uncertain \\
\hline The teacher uses word relay after the discussion. & 3.156 & 1.2262 & Uncertain \\
\hline $\begin{array}{l}\text { The teacher employs games in activities such as } 4 \text { pics } 1 \text { word, guess } \\
\text { what, quiz bee, jigsaw puzzle etc. }\end{array}$ & 3.149 & 1.3428 & Uncertain \\
\hline $\begin{array}{l}\text { The teacher employs moving test during quizzes, unit test and other } \\
\text { tests. }\end{array}$ & 2.764 & 1.3982 & Uncertain \\
\hline $\begin{array}{l}\text { The teacher asks the students to play/present a short skit in applying the } \\
\text { lessons they have learned. }\end{array}$ & 2.7 & 1.3694 & Seldom \\
\hline
\end{tabular}

The table presented above are the selected teaching strategies of the dressmaking teachers of Reina Mercedes Vocational and Industrial School that are perceived by the dressmaking students. The teacher orients the students in maintaining and troubleshooting sewing machine, The teacher guides the students the proper use of sewing tools and equipment, The teacher motivates the students by giving them credits if they accomplish the task or activity before the deadline, The teacher demonstrates actual drafting, cutting, lay outing before the students do their work perceived as "Always".

While the teaching strategies that perceived as "Sometimes" are the following: The teacher assists the students in doing their works and The teacher uses modules in disseminating the ideas or the lesson.

The finding of the study corroborates the study of Navaro, Cruz, and Tovera (2012), it stated that the first task of the teacher is motivating, orienting and guiding learning activities. Much of the success or failure of instruction in the classroom depends on the amount of orientation and motivation of the students to learn.

Table 3. Effectiveness of the Teaching Techniques and Strategies of the Dressmaking Teachers.

\begin{tabular}{lccc}
\hline Statement & Mean & S.D. & Description \\
\hline Effects to the students & & & \\
I know the proper use of sewing tools and equipment. & 4.213 & 0.9591 & Always \\
I am encouraged to improve my grades. & 4.195 & 0.9981 & Sometimes \\
I develop my sewing skills (drafting, lay outing, cutting, and etc. & 4.047 & 1.0617 & Sometimes \\
A sewing machine I learn how to maintain and troubleshoot. & 4.03 & 0.8319 & Sometimes \\
I gain self-confidence. & 3.943 & 0.9632 & Sometimes \\
I am more active in participating class or group discussion. & 3.91 & 0.9 & Sometimes \\
I am motivated in participating during discussion. & 3.875 & 0.9567 & Sometimes \\
I learn to maintain and troubleshoot sewing machine. & 3.865 & 0.9908 & Sometimes \\
I developed my social skills. & 3.862 & 0.9785 & Sometimes \\
I become more responsible. & 3.843 & 0.9641 & Sometimes \\
I participated in every discussion and recitation. & 3.83 & 0.8998 & Sometimes \\
I easily grasp the lessons being taught. & 3.575 & 1.0744 & Sometimes \\
I receive credits to my teacher if I finish my work before the deadline. & 3.398 & 1.3437 & Sometimes \\
\end{tabular}


The table above displays the perception of the respondents in terms of the effectiveness of the teaching techniques and strategies employed by the dressmaking teachers. It can be deduced from the findings that the dressmaking teachers are knowledgeable when it comes to teaching.

As can be glean in the table, the effects of the teaching techniques and strategies that were perceived as "always" is I know the proper use of sewing tools and equipment.

While the effects of these teaching techniques and strategies as "sometimes" are: I am encourage to improve my grades, I develop my sewing skills (drafting, lay outing, cutting and etc.), A sewing machine I learn how to maintain and troubleshoot, I gain self-confidence, I am more active in participating class or group discussion, I am motivated in participating during discussion, I learn to maintain and troubleshoot sewing machine, I developed my social skills , I become more responsible, I participated in every discussion and recitation, I receive credits to my teachers if I finish my work before the deadline.

\section{SUMMARY OF FINDINGS}

This study utilized a Descriptive - Quantitative survey design focused on the perceptions of the dressmaking students about selected teaching techniques and strategies, and their effects employed by the dressmaking teachers of Reina Mercedes Vocational and Industrial School.

In gathering the data, the researchers used a self-made survey questionnaire as a research instrument, based on the data presented and analyzed, the researchers came out with the following findings:

1. The teaching techniques used by the dressmaking teachers are the following:

- The teacher demonstrates the steps in drafting, layouting and cutting.

- The teacher sets due date to accomplish the project/job.

- The teacher presents energizer/motivation before the classes starts.

- The teacher catches he students' attention when they are noisy.

- The teacher corrects students' error constructively and supplies them with the correct answers.

- The teacher uses concrete examples in delivering the lessons.

- The teacher asks evaluative questions during and after the discussion.

- The teacher allows the students to use their mother tounge in sharing their ideas, thoughts and feelings towards the lesson.

- The teacher provides outline advance organizer or visual guides.

- The teacher writes the key terms on the board and gives emphasis on it.

- The teacher inserts jokes in explaining the topic.

- The teacher uses modulated and different rhythm of voices to motivate the students.

2. The teaching strategies used by the dressmaking teachers are the following:

- The teacher guides the students the proper use of sewing tools and equipment.

- The teacher demonstrates actual drafting, lay outing and cutting before the students do their work.

- The teacher orients the students in maintaining and troubleshooting a sewing machine.

- The teacher assists students in doing their works.

- The teacher uses modules in disseminating the ideas or the lesson.

- The teacher motivates the students by giving them credits if they accomplish the task or activity before the deadline.

- The teacher uses semantic webbing in presenting, explaining and elaborating the topic or the lesson.

- I participated in every discussion and recitation. 
3. Effects of the teaching techniques and strategies to the dressmaking students:

- I know the proper use of sewing tools and equipment.

- I am encouraged to improve my grades.

- I develop my sewing skills (drafting, lay outing, cutting, and etc.

- A sewing machine I learn how to maintain and troubleshoot.

- I gain self-confidence.

- I am more active in participating class or group discussion.

- I am motivated in participating during discussion.

- I learn to maintain and troubleshoot sewing machine.

- I developed my social skills.

- I become more responsible.

- I easily grasp the lessons being taught.

- I receive credits to my teacher if I finish my work before the deadline.

\section{CONCLUSIONS}

Based on the data presented, the researchers concluded that:

1. Most of the teaching techniques used by the dressmaking teachers are habitual or usual techniques.

2. Majority of the strategies employed by the dressmaking teachers are actual performance of the students.

3. It can be concluded that the dressmaking teachers employ teaching techniques and strategies that really help the students in their study.

\section{RECOMMENDATIONS}

Based on the study conducted, the researchers recommend the following:

1. More activities should also given to the students in order to further enhance their knowledge on the subject matter being tackled and also as a means of preparing them for the future assessment.

2. The dressmaking teachers should be more innovative in the use of different teaching techniques and strategies in order to maintain the interest and attention of the students during class discussion.

3. The administration should also give the dressmaking teachers the opportunity to attend different seminars to keep them updated if there are any revisions and also about the latest information about the dressmaking subject.

\section{ACKNOWLEDGEMENTS AND LEGAL RESPONSIBILITY}

A heartfelt gratitude and sincere appreciation to the Reina Mercedes Vocational and Industrial School Faculty who served as an evaluator to this study, Mr. Rodelio L. Pinugu - School Principal IV, Noralyn D. Nagum - Assistant School Principal II, Department of Education - Division of Isabela, Mr. Ariel D. Dumlao for making this endeavour possible.

\section{REFERENCES}

Costa ML, Van Rensburg L and Rushtun N. (2007). Does teaching style matter? A randomised trial of group discussions verses lectures in orthopedic under graduate teaching medical education, 41:214217. 
Dimopoulos D. Paraskeuopoulos S. and Pantis JD. (2008). The cognitive and Attitudinal Effects of a Conservation Educational Module on Elementary School Students. Spring, 39(3):47-61.

Lord TR. (2001). 101 Reasons for using cooperative learning in biology teaching. The American Biology Teacher, 63(1):30-38.

Aivazidis C. Lazaridone M. and Hellden GF. (2006). A comparison between a Traditional and an Online Environmental Education Program. The Journal of Environmental Education. 37(4):45-54

Brosh, H. (1996). Perceived characteristics of the effective language teacher. Foreign Language Annals, 29(2), 125-136

Wang, W, Y. (2002). Effects of gender and proficiency on listening comprehension strategy use by Taiwanese EFL Senior High School Students - a case from Changua, Taiwan (Master's thesis). Retrieved from Electronic Thesis and Dissertations System (090NCUE240001)

Chen, Y.C. (2008). An investigation of the relationship between teaching style and studies achievement in MiaoliLianguo Senior High School. (Unpublished master's thesis). Hsuan Chuang University, Miaoli, Taiwan.

Durlak, J. A (2011). The Impact of Enhancing Students Social and Emotional learning: a meta-analysis of school-based Universal interventions. Child Development, 82, 405-432.

Witzel, B. S. (2003). Teaching algebra to student with mathematical difficulties in inclusive settings. learning disabilities. A Contemporary Journal, 3(2), 49-60. 